a logical approach. If an insulinoma is suspected a means of confirming the diagnosis would be to take three morning plasma samples after an overnight fast. In a subject who has fasting hypoglycaemia an amended ratio of more than $50 \mu \mathrm{U} /$ $\mathrm{mg}$, in the absence of very severe obesity, is strongly suggestive of an insulinoma, and a ratio of more than $200 \mu \mathrm{U} / \mathrm{mg}$ would appear to be diagnostic. Very occasionally patients with extreme obesity, pregnancy, or liver disease with a portosystemic shunt might give "false-positive" results; in most doubtful cases an ethanol infusion could be performed as described elsewhere (Turner et al., 1971).

It has recently been shown that insulinomas secrete a high proportion of proinsulin (Melani et al., 1970a). This does not invalidate the examination of fasting insulin levels as a diagnostic measure, as a high level of immunoreactive insulin relative to the plasma glucose is the diagnostic feature-any cross-reacting proinsulin from an insulinoma would exaggerate an abnormal ratio.

We wish to thank the nursing staff of the Middlesex Hospital for their continued help; Professor V. Wynn for allowing us to investigate patients under his care, and for his advice and encouragement; Miss B. Schneeloch for technical assistance; the University of London Central Research Fund for providing the Technicon AutoAnalyzer at the Middlesex Hospital; the British Diabetic Association for grants to cover technical assistance; and Dr. Julia Ellis for anti-insulin serum (GP5).

\section{References}

Albano, J., Elkins, R. P., Maritz, G. G., and Turner, R. C. (1971). In

Cahill, G. F., et al. (1966). Fournal of Clinical Investigation, 45, 1751.

Cotes, P. M., et al. (1969). Fournal of Endocrinology, 45, 557.

Cramp, D. G. (1967). Fournal of Clinical Pathology, 20, 910.

Deckert, T., and Ege, P. (1970). Acta Medica Scandinavica, 187, 331.

Fajans, S. S. (1969). Excerpta Medica, International Congress Series, No. 172 , p. 894.

Felig, P., Marliss, E., and Cahill, G. F. (1969). New England fournal of Medicine, 281, 811 .

Floyd, J. C., Fajans, S. S., Knopf, R. F., Rull, J., and Conn, J. W. (1965). Clinical Research, 13, 322.

Goodner, C. J., Conway, M. J., and Werrbach, J. H. (1969). Fournal of Clinical Investigation, 48, 1878.

Grey, N. J., Goldring, S., and Kipnis, D. M. (1970). Fournal of Clinical Investigation, 49, 881 .

Grunt, J. A., Pallotta, J. A., and Soeldner, J. S. (1970. Diabetes, 19, 122. Hunter, W. M. (1969). Excerpta Medica, International Congress Series, No. 161, p. 551 .

Karam, J. H., Grodsky, G. M., and Forsham, P. H. (1963). Diabetes, 12, 197.

Marks, $\dot{V}_{\text {., and Lloyd, K. (1963). Proceedings of the Association of Clinical }}$ Biochemists, 2, 176

Marks, V., and Samols, S. (1969). Excerpta Medica, International Congress Series, No. 172, 864.

Martin, F. I. R., Pearson, M. J., and Stocks, A. E. (1968). Lancet, 1, 1285. Melani, F., Oyer, P., Rubenstein, A. H., and Steiner, D. F. (1970a). Excerpto Medica, International Congress Series, 209, p. 2 .

Melani, F., Rubenstein, A. H., and Steiner, D. F. (1970b). fournal of Clinical Investigation, 49, 497.

Investigation, 49, 497.
Perley, M., and Kipnis, D. M. (1966). Diabetes, 15, 867.

Sönksen, P. H., et al. (1967). Fournal of Clinical Endocrinology and Metabolism, 27, 1418

Turner, R. C., Oakley, N. W., and Nabarro, J. D. N. (1971). In press.

\title{
Pericarditis after Acute Myocardial Infarction
}

\author{
U. THADANI, M. P. CHOPRA, CLIVE P. ABER, R. W. PORTAL
}

British Medical fournal, 1971, 2, 135-137

\section{Summary}

Fifty-two (6.8\%) of 779 patients admitted to a coronary monitoring unit with acute myocardial infarction developed a pericardial friction rub. A diagnosis of postmyocardial infarction syndrome was made in three of these.

The course of the 52 patients with pericarditis was compared with that of a consecutive series of 100 patients without pericarditis. As a group those with pericarditis manifested a longer period of pyrexia, a greater rise in serum enzymes, and a higher incidence of major arrhythmias and of radiological pulmonary oedema. The Peel prognostic index, however, did not differ significantly in the two groups. The hospital mortality of the pericarditis group was not significantly different from that of the 727 non-pericarditis patients. No specially adverse features were found in a follow-up of the pericarditis group.

Though the presence of a pericardial rub in the first few days after a myocardial infarction may be a sign of extensive myocardial damage and is associated with a relatively high incidence of ventricular fibrillation, it does not appear to influence the hospital mortality of patients treated in a monitoring unit.

Department of Cardiology, Kingston General Hospital, Hull HU3 IUR U. THADANI, M.B., M.R.C.P., Registrar

M. P. CHOPRA, M.B., B.S., Research Assistant (Recipient of Research Grant from Leeds Regional Hospital Board)

CLIVE P. ABER, M.D., M.R.C.P., Consultant Physician

R. W. PORTAL, M.D., M.R.C.P., Consultant Physician

\section{Introduction}

A pericardial rub is a common physical sign after acute myocardial infarction. Since, however, it is usually a transient phenomenon it is often regarded as an incidental finding, hardly ranking as a complication. The pericarditis of the postmyocardial infarction syndrome commonly develops later in the illness, is more prolonged, may be recurrent, and was estimated by Dressler (1959) as occurring in 3 to $4 \%$ of cases.

Since the establishment of coronary care units no further clinical observations appear to have been made about this relatively common feature of acute myocardial infarction. The present study was therefore undertaken to determine the incidence of clinically recognizable pericarditis after acute infarction, and to establish whether its occurrence carried any immediate or long-term prognostic significance.

\section{Patients and Methods}

The 52 patients studied were among 779 (593 men and 186 women) with acute myocardial infarction admitted to a coronary monitoring unit between October 1967 and July 1970. The organization of the unit has been described (Aber et al., 1969). The diagnosis of infarction was based on a characteristic history, together with electrocardiographic evidence (World Health Organization (1959) criteria) and/or a significant rise of serum aspartate aminotransferase (glutamic oxaloacetic transaminase, SGOT) and serum $\alpha$-hydroxybutyrate dehydrogenase. SGOT levels were measured by a modification of the method of Babson et al. (1962) and serum $\alpha$-hydroxybutyrate dehydrogenase by the method of Elliott and Wilkinson (1961). The serum enzymes were estimated daily for three consecutive days. 
Conventional 12-lead E.C.G.s were recorded daily for at least three days and then weekly, or more often if indicated, during the patients' stay in hospital. A portable anteroposterior chest radiograph $(5 \mathrm{ft} ; 1.5 \mathrm{~m})$ was taken on admission and repeated if indicated. At least one $6-\mathrm{ft}(1.8-\mathrm{m})$ posteroanterior chest radiograph was obtained before discharge from hospital. A Peel prognostic index (Peel et al., 1962) was determined for each patient on admission.

Anticoagulant therapy (intravenous heparin 40,000 units daily for 48 hours and warfarin) was given to 30 of the 52 patients. Those over the age of 65 and those with a history of dyspepsia or hypertension did not receive anticoagulants.

The presence of a pericardial rub was agreed in all cases by two observers, including a senior member of the medical staff.

A "control" group was obtained for purposes of comparing some clinical, biochemical, and radiological features. It consisted of 100 consecutive patients ( 75 men and 25 women) with acute infarction who did not show a pericardial rub and who survived long enough for the ap rorriate observations to be made.

All patients with a pericardial rub who survived to leave hospital were followed up for 2 to 36 months after infarction. Special note was made of recurrence of pericarditis, the late development of cardiac failure, the presence of an abnormal cardiac impulse, the persistence of ST elevation in the E.C.G., and their capacity for work.

\section{Results}

Pericardial Rub.-A pericardial rub was heard in $52(6.8 \%)$ of the 779 patients with acute infarction (44 men and 8 women). Their ages ranged from 39 to 74 years. The rub was heard on the first day after infarction in 6 patients, on the second day in 19, on the third day in 16, and on the fourth day in 7 . In only four patients $(8 \%)$ did the rub become audible later than the fourth day (one on the fifth, two on the sixth, and one on the eleventh day). In 46 patients ( $89 \%$ ) the rub remained audible from one to six days and did not recur, and in the other six it persisted for 8 to 16 days. In two of them it recurred and a diagnosis of postmyocardial infarction syndrome was subsequently made. Six patients developed the pericardial rub between 12 and 110 hours after successful management of primary ventricular fibrillation by external cardiac massage and D.C. shock.

Peel Prognostic Index. - There was no significant difference between the scores of the two groups of patients (Table I) $(\mathrm{P}>0.5)$. TABLE I-Prognostic Indices (Peel et al., 1962) of 100 Patients with Acute
Myocardial Infarction without Pericarditis Compared with 52 Patients with Myocardial

\begin{tabular}{lcc|c|c|c|c}
\hline & & & \multicolumn{4}{c}{ Peel Index } \\
\hline \multicolumn{2}{c|}{ Group } & & $1-8$ & $9-12$ & $13-16$ & $\geqslant 17$ \\
\hline $\begin{array}{l}\text { Control } \\
\text { Pericarditis }\end{array}$ & $\cdots$ & $\cdots$ & $69(69 \%)$ & $19(19 \%)$ & $9(9 \%)$ & $3(3 \%)$ \\
& & $\cdots$ & $33(63 \%)$ & $10(19 \%)$ & $6(12 \%)$ & $3(6 \%)$ \\
\hline
\end{tabular}

*A high score denotes a poor prognosis.

Pyrexia.-An oral temperature exceeding $99^{\circ} \mathrm{F}\left(37.2^{\circ} \mathrm{C}\right)$ was present in 49 patients $(94 \%)$ in the pericarditis group, compared with $72(72 \%)$ in the control group. The pyrexia lasted for more than six days in 20 patients $(38.5 \%)$ in the pericarditis group, compared with five patients $(5 \%)$ in the control group.

Electrocardiograms. - The location of the myocardial infarction in the two groups is shown in Table II. Serial tracings in the pericarditis group were examined for features ascribable to pericarditis rather than to infarction alone. Though no distinctive pattern emerged it was noted that in anterior infarction ST elevation sometimes occurred in the posterior leads without the later development of $Q$ waves in these leads. Though in Table II such patients are listed as having had combined anterior and posterior infarction, these E.C.G. changes could be interpreted as a manifestation of a diffuse pericarditis.

TABLE II-Electrocardiographic Location of Myocardial Infarction in 100 Patients without and 52 Patients with Pericarditis

\begin{tabular}{|c|c|c|c|c|}
\hline \multicolumn{3}{|c|}{ Site of Infarction } & Control Group & Pericarditis Group \\
\hline $\begin{array}{lll}\text { Anterior } & . & \ldots \\
\text { Posterior } & \ldots & . \\
\text { Anterior and } & \text { posterior } & . \\
\text { Uncertain } & . . & .\end{array}$ & $\begin{array}{l}\ldots \\
\cdots \\
\cdots\end{array}$ & $\begin{array}{l}\ldots \\
\because \\
\cdots\end{array}$ & $\begin{array}{r}36(36 \%) \\
47(47 \%) \\
3(3 \%) \\
14(14 \%)\end{array}$ & $\begin{array}{r}23(44 \%) \\
18(34 \%) \\
5(10 \%) \\
6(12 \%)\end{array}$ \\
\hline
\end{tabular}

Chest Radiographs.-Chest radiographs were examined for evidence of pericardial effusion, pulmonary oedema, pleural effusion, and abnormal shadows in the lung fields. Pulmonary oedema was observed in eight patients $(8 \%)$ in the control group and in nine $(17.3 \%)$ in the pericarditis group $(P<0.06)$. No clear evidence of pericardial effusion was found. Pleural effusions were seen in only four patients $(7.7 \%)$ in the pericarditis group and in one patient $(1 \%)$ in the control group. No other significant abnormalities were observed.

Serum Enzymes.-The maximal levels of SGOT and serum $\alpha$-hydroxybutyrate dehydrogenase are shown in Table III and IV. High levels of both enzymes were more common in the pericarditis group than in the control group.

TABLE III-Maximal SGOT levels (units/ml) in 52 Patients with and 100 Patients without Pericarditis after Acute Myocardial Infarction

\begin{tabular}{cc|c|c|c|c|c|c}
\hline Group & & $1-$ & $101-$ & $201-$ & $301-$ & $401-$ & $501-$ \\
\hline $\begin{array}{ccc}\text { Control (\%) } \\
\text { Pericarditis (\%) }\end{array}$ & $\ldots$ & 26 & 43 & 22 & 4 & 5 & 10 \\
\hline
\end{tabular}

TABLE IV-Maximal Serum -Hydroxybutyrate Dehydrogenase (units/ml) in 52 Patients with and 100 Patients without Pericarditis after Acute Myocardial Infarction

\begin{tabular}{c|c|c|c|c|c|c|c|c}
\hline Group & $1-$ & $501-$ & $1,001-$ & $1,501-$ & $2,001-$ & $2,501-$ & $3,001-$ & $3,501-$ \\
\hline $\begin{array}{c}\text { Control (\%) } \\
\text { Pericarditis (\%) }\end{array}$ & 21 & 45 & 21 & 9 & 1 & 2 & 2 & 1 \\
\hline
\end{tabular}

Arrhythmias. - The incidence of major arrhythmias (atrial fibrillation, atrial flutter, supraventricular tachycardia, ventricular fibrillation, complete heart block, and asystole) is shown in Table V. Five patients $(5 \%)$ in the control group and eight $(15 \%)$ in the pericarditis group developed more than one major arrhythmia (Table V). Though arrhythmias occurred with a higher frequency in the pericarditis group, there was no temporal relation between the development of the pericardial rub and the onset of the arrhythmia.

TABLE v-Incidence of Major Arrhythmias after Acute Myocardial Infarction in 100 Patients without and 52 with Pericarditis

\begin{tabular}{|c|c|c|c|c|c|c|}
\hline & & & & & $\begin{array}{l}\text { Control } \\
\text { Group }\end{array}$ & $\begin{array}{l}\text { Pericarditis } \\
\text { Group }\end{array}$ \\
\hline $\begin{array}{l}\text { Supraventricular Tachycardia } \\
\text { Ventricular Tachycardia } \\
\text { Ventricular Fibrillation }\end{array}$ & $\cdots$ & $\because$ & $\because$ & . & $11(11 \%)$ & $\begin{array}{r}17(33 \%) \\
2(4 \%)\end{array}$ \\
\hline 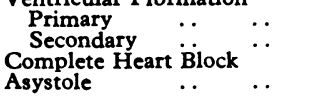 & $\begin{array}{l}\ldots \\
\cdots \\
\cdots\end{array}$ & $\begin{array}{l}\ldots \\
\cdots \\
\cdots\end{array}$ & $\begin{array}{l}\ldots \\
\cdots \\
\cdots\end{array}$ & $\begin{array}{l}\ldots \\
\cdots \\
\cdots\end{array}$ & $\begin{array}{ll}6 & (6 \%) \\
3 & (3 \%) \\
3 & (3 \%) \\
1 & (1 \%)\end{array}$ & $\begin{array}{l}7(13.5 \%) \\
3 \quad(6 \%) \\
7(13.5 \%) \\
1 \quad(2 \%)\end{array}$ \\
\hline
\end{tabular}

Mortality.-Ten (19\%) of the 52 patients with pericarditis died in hospital within 17 days of infarction. By comparison $93(13 \%)$ of the remaining 727 patients in the total series died in hospital. The difference is not significant $(P>0.2)$. Of the 10 deaths in the pericarditis group the terminal event was 
ventricular fibrillation in three patients (primary in one and secondary in two), complete heart block in two, ventricular asystole in one, a cerebrovascular accident in two, and bronchopneumonia in one. One patient was found dead.

Follow-up.-Forty-two patients with pericarditis were reviewed after leaving hospital. Two of them died two and four months after discharge. Among the survivors the incidence of angina, further infarction, cardiac failure, abnormal cardiac impulse (suggestive of a cardiac aneurysm), persisting ST elevation, and work record is given in Table VI.

TABle vi-Follow-up Data on 42 Patients with Pericarditis after Acute Myocardial Infarction

\begin{tabular}{|c|c|c|c|c|c|c|c|}
\hline & & & & & & & $\begin{array}{c}\text { No. of } \\
\text { patients }\end{array}$ \\
\hline $\begin{array}{l}\text { Angina } . . \\
\text { Further infarction } \\
\text { Persistent heart failure } \\
\text { Abnormal cardiac impulse } \\
\text { Persistent ST elevation ... } \\
\text { Deaths after discharge... } \\
\text { Work record (35 patients)* } \\
\text { Original job ... } \\
\text { Change of employment }\end{array}$ & $\begin{array}{l}\cdots \\
\cdots \\
\cdots \\
\cdots \\
\cdots\end{array}$ & $\begin{array}{l}\cdots \\
\cdots \\
\cdots \\
\cdots \\
\cdots\end{array}$ & $\begin{array}{l}\cdots \\
\cdots \\
\cdots \\
\cdots \\
\cdots\end{array}$ & $\begin{array}{l}\because \\
\because \\
\because \\
\because \\
\end{array}$ & $\begin{array}{l}\cdots \\
\cdots \\
\cdots \\
\cdots \\
\cdots\end{array}$ & $\begin{array}{l}\ldots \\
\because \\
\therefore \\
\cdots \\
\cdots\end{array}$ & $\begin{array}{r}11(26 \%) \\
3(7 \%) \\
2(5 \%) \\
7(17 \%) \\
10(24 \%) \\
2(5 \%)\end{array}$ \\
\hline
\end{tabular}

* Seven Patients were not working before infarction.

Postmyocardial Infarction Syndrome.-This diagnosis was made in three patients. The initial pericardial rub developed within five days of infarction and lasted from 8 to 12 days. In two of these patients the pericardial rub returned in the fourth week, whereas in one patient pericardial pain recurred in the seventh week. In all there was a recurrence of fever, in one there was radiological evidence of a transient pericardial effusion, and in another pleural pain with effusion.

\section{Discussion}

The reported frequency of a pericardial friction rub after myocardial infarction varies widely. Rosenbaum and Levine (1941) quoted a range of 7 to $42 \%$ in earlier papers, and an incidence of $16 \%$ in their own series of 206 patients. Wood (1968) gave the incidence as about $10 \%$. Our current incidence of $7 \%$ agrees with that of Parkinson and Bedford (1928). We have included in the present study only subjects in whom a pericardial rub was unequivocally heard. Other patients experienced rather prolonged precordial pain after their infarction, which was sometimes aggravated by movement or inspiration, and which may have been a manifestation of pericarditis.

The rub developed within four days of infarction in $92 \%$ of patients and remained audible for less than six days in $88 \%$. In only two patients did it recur, and in these the diagnosis of postmyocardial infarction syndrome was finally made. The development of a rub in six patients after primary ventricular fibrillation and successful resuscitation was probably coincidental rather than attributable to trauma from external cardiac massage.

A pericardial rub was not confined to those with anterior or anterolateral necrosis. Stewart and Turner (1938) and Rosenbaum and Levine (1941) also pointed out that the presence of a rub does not identify the site of infarction. The development of pericarditis within a few days of infarction is usually taken as a sign that the subepicardial myocardium has been involved, and the sparing of this layer may be the reason for the low incidence of clinically detectable pericarditis (Parkinson and Bedford, 1928). For this reason the presence of a friction rub has been recognized as a sign of extensive infarction (Rosenbaum and Levine, 1941). Our own experience supports this view, for the maximal rise in serum enzymes tended to be greater in those with pericarditis than in those without, and within the pericarditis group itself the mortality was highest among those with the highest enzymes, a correlation noted by Rosalki (1963). Further indirect evidence of extensive necrosis in the pericarditis group is provided by the higher incidence of radiological pulmonary oedema among these patients. The longer duration of fever in the pericarditis group may also be a manifestation of greater myocardial damage, though it could equally well be interpreted as a sign of pericardial "inflammation."

Though the incidence of major arrhythmias was two to three times higher in the pericarditis group, the hospital mortality was not significantly different from that in the 727 nonpericarditis patients. Moreover, the development of a pericardial rub after recovery from primary ventricular fibrillation did not carry a poor prognosis, for all these six patients survived.

The follow-up study failed to show any cause for pessimism regarding the long-term prognosis in the pericarditis group.

The diagnosis of postmyocardial infarction syndrome in only 3 out of our total series of 779 patients with acute infarction gives an incidence approaching that of Broch and Ofstadt (1960) and Davidson et al. (1961), who reported 1\% or less, but lower than the estimated three to $4 \%$ suggested by Dressler (1959). In part this discrepancy might be explained by the unrecognized development of the syndrome at home after the earlier discharge from hospital now customary. It is clear that no infallible demarcation line can be drawn between the "simple" pericarditis due to involvement of the surface of the heart by the infarct and the much rarer postmyocardial infarction syndrome. The difficulties encountered in separating the syndrome from other common complications of acute infarction have been stressed by Weiser et al. (1959, 1962), who question whether the radiological pulmonary infiltration ("pneumonitis") sometimes reported is not a manifestation of left ventricular failure. We have observed no radiological changes in heart size or lung fields in the patients with "simple" pericarditis which could not be explained by cardiac failure. It therefore seems unlikely that the syndrome has been greatly underdiagnosed during the period of hospital observation.

Anticoagulants were given in $57 \%$ of the patients with pericardial friction rubs. No evidence of haemorrhagic pericardial effusion was forthcoming, though this complication has been reported (Goldstein and Wolff, 1951; Fell et al., 1965; Miller, 1969). This risk would therefore seem small, and the supervention of a pericardial rub after infarction is not in itself an indication to terminate this form of therapy. Since $43 \%$ of the patients with pericarditis had never received anticoagulants, it seems unlikely that anticoagulant therapy plays any part in the development of this complication.

\section{References}

Aber, C. P., Portal, R. W., and Chopra, M. P. (1969). British Medical fournal, 1, 209.

Babson, A. L., Shapiro, P. O., Williams, P. A., and Phillips, G. E. (1962). Clinica Chimica Acta, 7, 199 .

Broch, O. J., and Ofstadt, J. (1960). Acta Medica Scandinavica, 166, 281. Davidson, C., Oliver, M. F., and Robertson, R. F. (1961). British Medical Fournal, 2, 535 .

Dressler, W. (1959). Archives of Internal Medicine, 103, 28.

Elliott, B. A., and Wilkinson, J. H. (1961). Lancet, 1, 698.

Fell, S. C., Rubin, I. R., Enselberg, C. D., and Hurwitt, E. S. (1965), New England fournal of Medicine, 272, 670 .

Goldstein, R., and Wolf, L. (1951). Fournal of the American Medical Association, 209, 1362.

Miller, R. L. (1969). Fournal of the American Medical Association, 209, 1362. Parkinson, J., and Bedford, D. E. (1928). Lancet, 1, 4.

Peel, A. A. F., Semple, T.; Wang, I., Lancaster, W. M., and Dall, J. L. G. (1962). British Heart fournal, 24, 745.

Rosalki, S. B. (1963). British Heart fournal, 25, 795

Rosenbaum, F. F., and Levine, S. A. (1941). Archives of Internal Medicine, 68, 913 .

Stewart, C. F., and Turner, K. B. (1938). American Heart fournal, 15, 232.

Weiser, N. J., Kantor, M., and Russell, H. K. (1959). Circulation, 20, 371. Weiser, N. J., Kantor, M., Russell, H. K., and Murphy, L. (1962) Circulation, 25, 643.

Wood, P. (1968). Diseases of the Heart and Circulation, 3rd edn. London,

Eyre and Spottiswoode.
World Health Organization (1959). Technical Report Series, No. 168. 